\title{
Success Factors for Initial Works of Industralised Building System Process of Projects Implementation
}

\author{
Faridah Ismail, Norazian Mohamad Yusuwan, Har Einur Azrin Baharuddin
}

\author{
Faculty of Architecture, Planning \& Surveying \\ Universiti Teknologi MARA, Shah Alam, MALAYSIA \\ farid346@salam.uitm.edu.my
}

\begin{abstract}
The absence of success factors focusing on the Industrialised Building System (IBS) process of project implementation initiates this study. Therefore, the aim of this research is to establish the success factors within the initial works of the IBS process of project implementation. Comprehensive literature review revealed that success factors are; the management, the government policies and initiatives, the coordination between design and construction, and the technical aspects of project deliverables. Questionnaire survey distributed amongst G7, IBS contractors unanimously agreed on these as success factors for the initial works of the IBS process of project implementation.

Keywords: Management Factors; Industrialised Building System; Successful Project Implementation; IBS Processes

eISSN 2514-751X @ 2018. The Authors. Published for AMER ABRA cE-Bs by e-International Publishing House, Ltd., UK. This is an open-access article under the CC BY-NC-ND license (http://creativecommons.org/licenses/bync-nd/4.0/). Peer-review under responsibility of AMER (Association of Malaysian Environment-Behaviour Researchers), ABRA (Association of Behavioural Researchers on Asians) and cE-Bs (Centre for EnvironmentBehaviour Studies), Faculty of Architecture, Planning \& Surveying, Universiti Teknologi MARA, Malaysia.

DOI: https://doi.org/10.21834/aje-bs.v3i9.305
\end{abstract}




\subsection{Introduction}

Previous studies on success factors focus on insurance (York, 1988), project life cycle, human resource (Jeffrey et al, 1988), development program on organizational effectiveness (Colin Coulson-Thomas,1990), hierarchy for construction project success (Robert et al. 1995, Chua, et al. 1999), TQM implementation (Jiju A. et al. 2002, Harjeev K. et al. 2011), strategic planning process (Joel K. et al. 2002), sixsigma for a manufacturing industry (Yi-zhong M. et. al. 2008), hierarchical model for competition strategy management (Kwai-Sang et al. 2008), IBS contractors (Mohamad Kamar, Abd Hamid and Alshawi,2009), leadership performance (Nixon. P, et al. 2012), public private partnership project (Esther C. et al. 2012). Thus, studies on success factors covered various discipline and areas. However, generally, success factors are closely related with management, the government policies and initiatives, the coordination between design and construction, and the technical aspects of project deliverables.

The absence of success factors focusing on the Industrialised Building System process of project implementation initiates this study. The IBS process includes the initial works, components production at a factory, transported to the construction site, installation and completion, initiated this study. Therefore, the aim of this research is to establish the success factors within the initial works of IBS process of project implementation.

The current IBS systems used in Malaysia housing projects are large panel systems, metal form systems and modular system. The IBS system is largely used in Shah Alam, Wangsa Maju and Pandan area (Sumadi et al, 2001). In large public and private buildings and infrastructure projects, pre-cast panel, steel frame and other IBS systems were used as hybrid construction technique to build national landmarks such as Bukit Jalil Sport Complex, Kuala Lumpur Convention Centre, Lightweight Railway Train (LRT) and Petronas Twin Towers (Mohamad Kamar \& Abdul Hamid, 2011).

There is an agreement among all researchers that IBS involved manufactured products or components (Abd Shukor et al, 2011; Leasing et al, 2005; CIDB, 2003; Warszawski, 1999; Esa And Nurudin, 1998). Junid (1986) and Trikha (1999) used the term "fabricated" and "prefabricated" respectively instead to address the similar characteristics of the products. A systematic approach that involved several processes are also agreed by all researchers.

\subsection{IBS Process of Project Implementation}

Construction of a conventional building has different stages according to the type of project and demographic. According to Yusop et al (2005), there are five stages involves in the 
conventional construction process. Figure 1.0 shows the typical construction process from planning stage until handing.

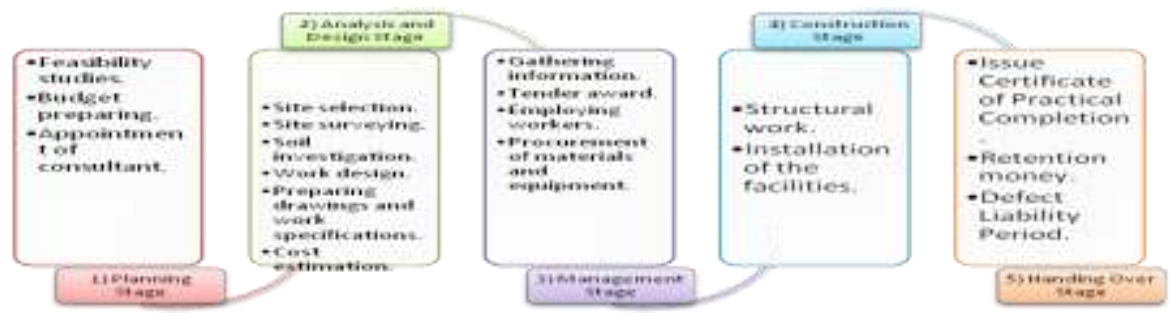

Figure 1.0: Typical Construction Process (Yusop et al, 2005)

Different with the management process of IBS, the systematic installation of each beam, column, wall or plank is carried out after the successful production of components. The substructure of the building would have been meticulously prepared months in advance. After the position of the starter bar has been accurately surveyed with a 'total station', a crane is used to lift the components to position on the starter bar or tie bar. To ensure verticality, temporary supporting stands are used to prop up the column. Grout is then poured into the holes that were prepared during casting for the insertion of the starter bar (Lim \& Kadir, 2006). The IBS process of project implementation is illustrated as in Figure 2.0.
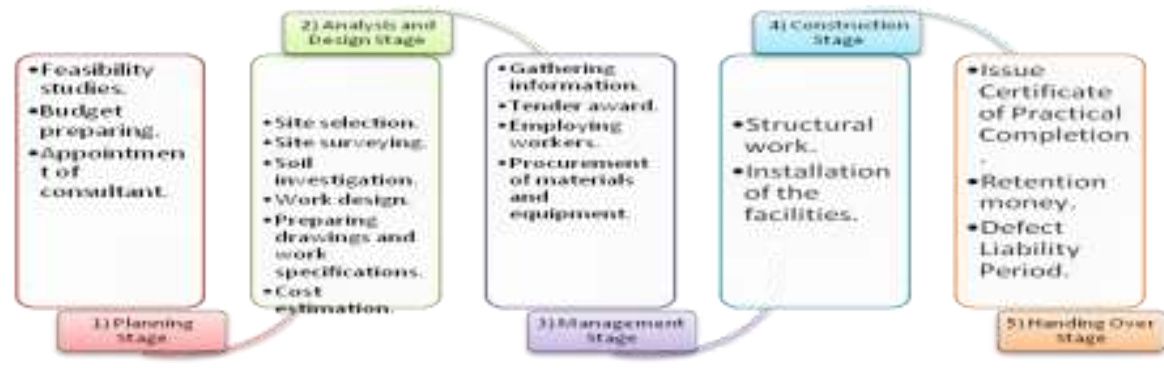

Figure 2.0: The IBS process of Project Implementation (Adopted from Yusop et al, 2005)

For every process of IBS project, the four factors for successful project implementation include management, government policies and initiatives, design and construction, and technical. Thus, this research will focus on these factors during the initial works of IBS process.

\subsection{Management}

The management factors of success in the initial works are good working collaborations, 
effective communication channel, team members involved during the design stage, extensive planning and scheduling, improvement in planning and scheduling of the project, risk management, management of supply chain and logistics, top-down commitment, strategy and business approach, industry marketing strategies. The details on the management related factors were discussed earlier (Faridah et al, 2012).

\subsection{Government Policies and Initiatives}

The government policies and initiatives factor in the initial works of IBS process include the use of IBS in government projects, reduce foreign workforce, and levy exemption incentives on IBS usage in a project. In line with the target of IBS Roadmap 2003-2010, Budget 2005 declared that all new government building projects are required to have at least $50 \%$ IBS content. In order to attract private clients, the second announcement was on the levy exemption for housing projects that have a minimum IBS Score of $50 \%$. Since then, and boosted by the Construction Industry Master Plan 2006-2015 and 9th Malaysia Plan 20062010, numerous activities have been executed by the Government (Treasury Circular, 2008). In terms of government policies and initiatives, the use of IBS in government project makes this system well known. Adhere to the policies set is essential during the initial works of IBS process.

The government's multi-pronged effort to reduce the number of foreign workers in the country has been successful with a marked reduction of the foreign worker population in May 2009 from 2.1 million in to 1.9 million at present (NST, 2012). Thus, the engagement of foreign workforce allows the flow of the government budget to an outside country (Shari et al, 2003).

Levy exemption incentives will attract contractor to verge the IBS project. As part of the push for the utilisation of Industrialised Building Systems, a number of incentives and regulatory requirements have been put forward. An example of a regulatory requirement is the minimum percentage of utilisation of IBS in a government building projects. Likewise, the minimum percentage requirement is also needed for CIDB levy exemptions. Consequently, some form of IBS content assessment is needed for the purpose. A levy exemption incentive is needed in the initial work of IBS process to ensure successful project implementation (CIDB, 2005).

\subsection{Design and Construction}

In term of design and construction factor in the initial works of IBS process, include coordination of design, manufacture and construction, key decisions on strategy, application, design, logistic and detail unit should be made as early as possible between all parties. Project Managers and Construction Group personnel work closely from project initiation through final inspection. Coordination between the staffs of these sections is the key to successful project completion. Coordination of 
design, manufacture and construction should be well planned to avoid project delayed. The time phase of design, manufacture and construction that involves in IBS process should have small deviation (Rahman \& Omar, 2006).

The key decision made by the project manager influenced the success factor of IBS project implementation. It is essential in components production at the factory and installation. Key decisions on strategy, application, design, logistics and detail unit should be made as early as possible between all parties involved (Gibb, 1999 \& Neale et al, 1993). It should not be used as an afterthought, or as a late solution to shorten construction time, but rather as an integral part of the design from the earliest possible stage of the project (Gibb, 1999 and Blissmas et al 2006).

\subsection{Technical}

Technical factor in the initial works of IBS process includes experienced workforce and technical capability, information and communication technology, continuous improvement and learning, and improvement in procurement strategy and contracting. Experienced workforce and technical capability is an enabler of good production (Lim \& Kadir, 2006). In all stages of IBS process including initial works, components production at a factory, transported to the construction site, installation and finishing, experienced workforce and technical capability is important to ensure successful IBS project implementation. In many markets and industries, workforce management is all about assigning the right employees with the right skills to the right job at the right time. The term is differentiated from traditional staff scheduling because staff scheduling is rooted to time management and simply manages the administration of past and future working times. This traditional approach has since evolved into the more integrated, demand-oriented workforce management, which includes changes in personnel requirements and objectives when optimising the scheduling of staff (DMG Consulting, 2009).

Information and communication technology is essential in all stages of IBS process including initial works. Information and communications technology or usually abbreviated as ICT, is often used as an extended synonym for information technology (IT), but is usually a more general term that stresses the role of unified communications and the integration of telecommunications (telephone lines and wireless signals), computers, middleware as well as the necessary software, storage and audio-visual systems, which enable users to create, access, store, transmit, and manipulate information. In other words, ICT consists of IT as well as telecommunication, broadcast media, all types of audio and video processing and transmission and network based control and monitoring functions (Grossman \& Helpman, 2005). This information and communication technology is very crucial to enable successful IBS project implementation.

Continuous improvement and learning should be apply in all stages of IBS process including initial works, components production at factory, transported to the construction site, installation and finishing. From continuous learning, all parties could take consideration to improve the production of IBS components. The management philosophy of W. Edwards Deming (1990) with its profound implications for management-led business transformation is 
underpinned by the practice of innovation and continuous improvement of systems and processes, based on understanding and knowledge. More recently, business process reengineering has been adopted by many organizations as a tool for a fundamental review of their key business processes and is providing many opportunities for significant step change improvements. It can also provide the added opportunity to design into the new process the capability of continuous ongoing improvement. Success in this area will depend on the ability of leaders, working in the process, and the overall system in which it operates, to create an environment where learning and innovation can be facilitated (Deming, 1990). This continues improvement and learning are crucial in order to gain successful IBS project.

During the commencement of IBS project, the procurement strategy and contracting that involved in the initial stage are important as all documentation including project cost are decided. Good planning from an early stage ensures the project to run smoothly. The purpose of improvement contracting and procurement is to maximise the benefit gained for client through robust contract negotiations with service providers, effective performance management of service providers and proactive market management of the service sector, whilst at the same time optimising all available national contracting routes, models and frameworks to achieve the aims of IBS production (Lim \& Kadir, 2006). This improvement of procurement strategy and contracting is crucial to achieve successful IBS project implementation. Table 1.0 illustrates the successful factors during the initial works of IBS process of project implementations.

Table 1.0: Success Factors for IBS Process Implementation

\begin{tabular}{|c|l|l|}
\hline IBS Process & Critical Success Factor & \multicolumn{1}{c|}{ Item } \\
\hline Initial Works & Management & $\begin{array}{l}\text { Good working collaboration, Effective communication } \\
\text { channel, Team members involved during the design stage, } \\
\text { Extensive planning and scheduling, Improvement in planning } \\
\text { and scheduling of the project, Risk management, } \\
\text { Management of supply chain and logistics, Top-down } \\
\text { commitment, Strategy and business approach, Industry } \\
\text { marketing strategies. }\end{array}$ \\
\cline { 3 - 4 } & & $\begin{array}{l}\text { Use of IBS in government project, Reduce foreign workforce, } \\
\text { Levy exemption incentives on IBS usage on a project. }\end{array}$ \\
\cline { 2 - 4 } & Government Policies and \\
& Initiatives & $\begin{array}{l}\text { Coordination of design, manufacture and construction, Key } \\
\text { decisions on strategy, application, design, logistics and detail } \\
\text { unit should be made as early as possible between all parties. }\end{array}$ \\
\cline { 2 - 4 } & Design and Construction & $\begin{array}{l}\text { Experienced workforce and technical capability, Information } \\
\text { and communication technology, Continuous improvement } \\
\text { and learning, Improvement in procurement strategy and } \\
\text { contracting. }\end{array}$ \\
\cline { 2 - 3 } & Technical & \\
\hline
\end{tabular}

\subsection{Methodology}

A total of 314 questionnaires were mailed to IBS contractors listed under Construction Industry Development Board directory. Out of 314 set of questionnaire distributed 39 were satisfactorily completed make up the total response rate of $12.4 \%$. Questionnaire survey is employed as a data collection method listing the four successful factors identified through 
the literature review exercise. This is also initially supported by preliminary interviews with industry practitioners specifically those who are involved with IBS project. A set of 5 pages of the questionnaire was formulated aimed to solicit their agreement on the factors identified. A five (5) point Likert scale where 1 represented strongly disagree and 5 represented strongly agree are used as the scale of measurement.

\subsection{Results and Discussions}

Majority of the respondent (57.9\%) have been in the industry for more than ten (10) years. Meanwhile, those who had an experience between 5 to 9 years made up the percentage of $29 \%$ and the remaining $13 \%$ of the respondents have been working in this industry for 1 to 5 years.

The survey result revealed that, more than three-quarters $(76 \%)$ of the respondents are working in the companies which had completed more than ten (10 projects for the past ten (10) years, while the other 24 percent of the respondent being attached in the company which already completed less than ten (10) projects for the past ten (10) years. However, the total number of the completed projects does not represent the total cost of the completed project.

More than half of the respondents $(58 \%)$ have been involved in less than ten (10) completed IBS projects, while the rest of $42 \%$ has been involved in more than ten (10) completed IBS projects. From the survey result, none of the respondents never been involved in IBS project, hence, the data gathered were considered adequate and reasonable to obtain sound judgment and opinion with regards to the management-related factors that greatly affect the successful implementation of IBS projects.

Following the interpretation of five (5) point Likert scales, the analysis of surveyed data indicated top ten (10) management-related factors that influenced the successful implementation of IBS projects by the means score ranging from 3.29 to 4.67 (Faridah et al, 2012). The respondents, on the average, strongly agree that good working collaboration is the primary factor contributes to the successful implementation of IBS project. It is crucial for the project management team, to establish a good relationship and collaboration among the project members from the moment the project starts up to completion to ensure the smooth running of the project. Industry marketing strategies (mean=4.59) and extensive planning and scheduling (mean=4.52) ranked as second and third most influential factors.

Figure 3.0 shows government policies and initiatives factors as successful IBS process project implementation. Less than half of the respondents (40\%) agree that use IBS in government project could succeed that kind of project. All of the sub-factors met at an average point where one third of the respondents $(25 \%)$ rated average to use of IBS in a government project, reduces foreign workforce and levy exemption. In terms of government policies and initiatives, the use of IBS in government project makes this system well known. In addition, levy exemption incentives will attract contractor to verge the IBS project. In all stages, reducing foreign workforce will ensure successful IBS project implementation as IBS involved with high skill in its production and installation. 


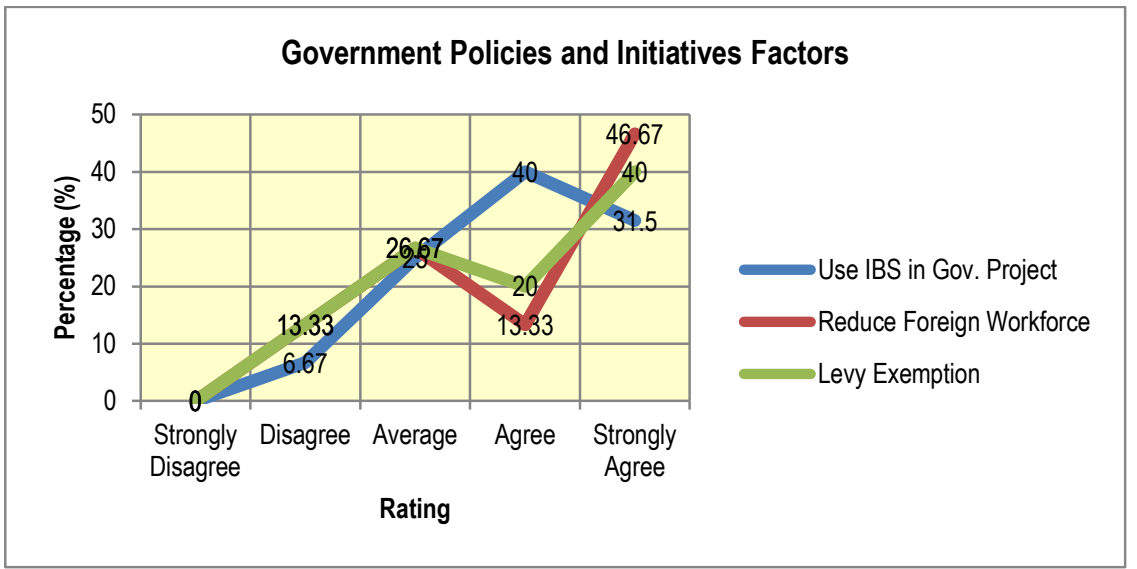

Figure 3.0: Government Policies and Initiatives Factors

Figure 4.0 shows the design and construction factors to successful IBS process project implementation. More than half of the respondents $(53.33 \%)$ agree that right design process is the critical factor meanwhile less than one third of the respondents (23.33\%) agrees with durability as the critical factor. For the balance sub-factors, more than one third of the respondents $(33.33 \%)$ agree that good appearance, design flexibility, tailor-made appearance, design standardisation, key decisions and coordination of construction are the critical factors for successful implementation of IBS project. Coordination of design, manufacture and construction should be well planned to avoid project delayed. The time phase of design, manufacture and construction that involves in production and installation stage should have small deviation. The key decision made by the project manager influenced the success factor of IBS project implementation. The components should have good appearance and design to produce high quality of IBS. The components also have to be durable, and maintenance requirement should take into account commencing from production at the factory and correct installation at site. During components production at factories, even though the design has to be standardized however repetition should be avoided. High quality tailor made appearance produce by better design is one of the factors in implementing successful IBS project. Flexibility of design increase market demand and the design process at the factory should be well supervised to produce a good product.

Figure 5.0 shows technical factors that lead to successful IBS project implementation. More than half of the respondents (54\%) agree that experience workforce leads to a successful IBS project. In the other hand, less than half of the respondents $(46.67 \%$ and 40\%) agree that Information Technology, hi-technology plant and equipment, continues improvement and learning, and skilled labor for site installation is important as a critical factor. More than one third of the respondents (26.67\%) agree with quality control and speed as a critical factor. During the commencement of IBS project, the procurement strategy and contracting that involved in the initial stage is important as all documentation including project cost are decided. From continuous learning, all parties could take consideration to improve 
the production of IBS components. Experienced workforce and technical capability is also as an enabler towards good production. In terms of technical factor, skilled labor for site installation is very crucial item to ensure successful IBS project implementation.

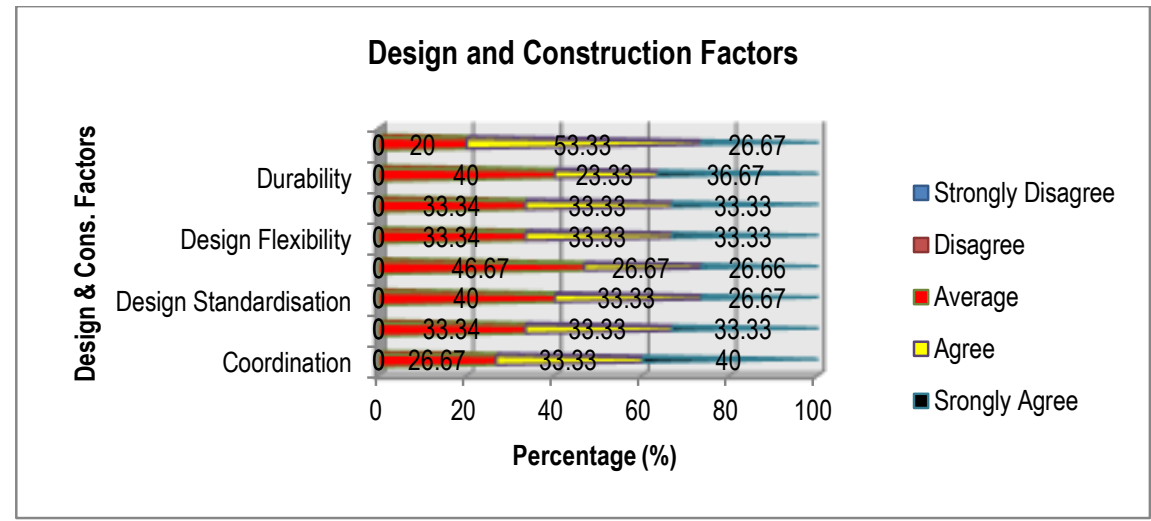

Figure 4.0: Design and Construction Factors

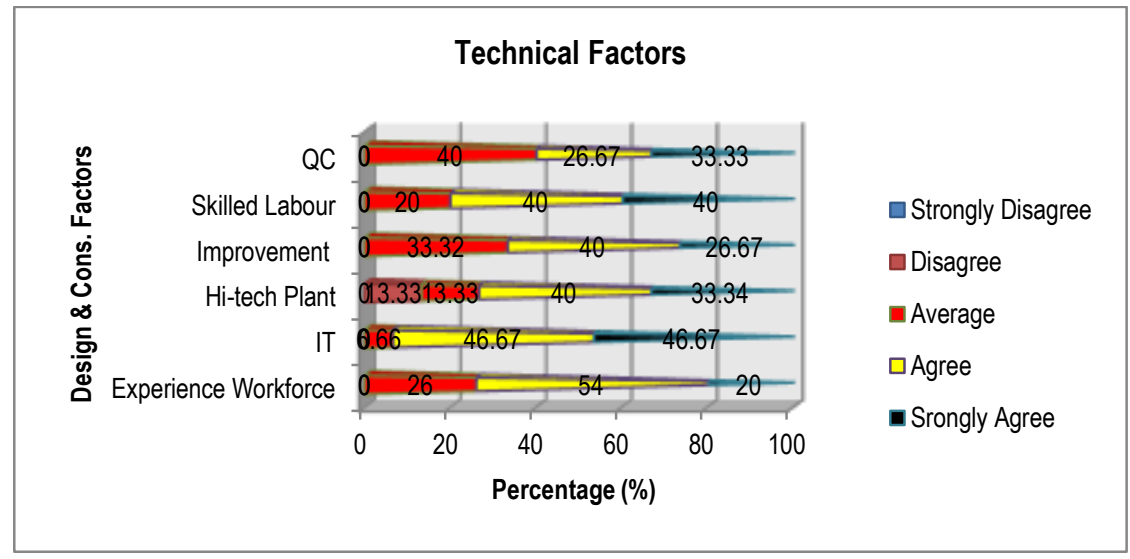

Figure 5.0: Technical Factors

\subsection{Conclusion}

Industrialised Building System (IBS) in Malaysia is perceived to be a system of construction which can offer benefits of speed, quality and safety to construction projects. IBS in Malaysia is also perceived to have a good technology. IBS, however, is not perceived to be a system which can provide cost reduction compared with traditional in-situ construction. In fact, IBS project proposals are often rejected solely on the basis of cost. There is a strong indication 
that many in the industry are reluctant to switch to the IBS method of construction. Consequently, many will not recommend the use of IBS in their future projects. Therefore, four success factors are identified to enable successful IBS process project implementation i.e. management, government policies and initiative, design and construction and technical. The research has successfully elaborate and identifies within the context of the initial works of IBS process.

Further, with a response rate of $12 \%$ disclose that the management factors indicated top ten (10) management-related factors. The government policies and initiatives factors show the level of agreement on the use IBS in government projects. However, other sub-factors met on average only in terms of reduction of foreign workforce and levy exemption. The design and construction factors revealed an agreement on the right design process, with the durability and the good appearance, design flexibility, tailor-made appearance, design standardisation, key decisions and coordination of construction are the factors for the initial IBS process project implementation. Technical factor in the initial works of IBS process includes experienced workforce and technical capability, information and communication technology, continuous improvement and learning, and improvement in procurement strategy and contracting are agreed upon among the Malaysian IBS contractors.

\section{Acknowledgements}

The authors would like to thank the Development Department of Universiti Teknologi MARA via the Research Management Institute of UiTM for funding this research.

\section{References}

Anna Nagurney (2006). Supply Chain Network Economics: Dynamics of Prices, Flows, and Profits. Edward Elgar Publishing, ISBN 1-84542-916-8.

Aziz, A. A. (2007), Adoption of Industrialised Building System in Malaysian Housing Industry, unpublished MSc Thesis University of Technology MARA (UiTM), Selangor, Malaysia.

Berawi M.A., Berawi, A.R.B., and Hadwart, K.A. (2012). Managing construction logistics management: Findings from construction contractors and industrialized building system (IBS) manufacturers. African Journal of Business Management. Vol. 6 (5), pp 1932-1944. doi: DOI: 10.5897/AJBM11.2047

CIDB (2003). Industrialised Building System Seminar 2003 - Towards Industrialisation Of Malaysian Construction Industry. Malaysia: CIDB Malaysia.

CIDB (2003). Global Trends in Research Development and Construction. Proceedings of the International Conference on Industrialised Building Systems, Malaysia: CIDB Malaysia.

CIDB (2009) Industrialised Building System (IBS): Implementation Strategy from R\&D Perspective. Construction Industry Development Board Malaysia (CIDB), Kuala Lumpur. 
CIDB (2010). Industrialised Building Systems (IBS) Roadmap 2003 - 2010. Malaysia: CIDB Malaysia.

CIDB Malaysia \& APEC Technology Foresight Centre (2000). Malaysian Construction Industry: Technology Foresight Report. Proceedings of the CIDB Workshop on Technology Foresight, CIDB, Kuala Lumpur.

CIDB Malaysia (2001). Manual for Assessment of Industrialised Building Systems. CIDB, Kuala Lumpur.

CIMP (2007) Construction Industry Master Plan 2006 - 2015 (CIMP 2006 - 2015). Construction Industry Development Board Malaysia (CIDB), Kuala Lumpur.

Chua, D., Kog, Y., and Loh, P. (1999). Critical Success Factors for Different Project Objectives.

J. Constr. Eng. Manage., 125(3), 142-150.

Colin Coulson-Thomas (1990). Human Resources: The Critical Success Factor. International Journal of Manpower, Vol. 11 Iss: 5, pp.34 - 36.

DMG Consulting (2009). Contact Centre Workforce Management Market Report.

E.G. Ochieng and a.D.F.Price (2009).Managing cross-cultural communication in multicultural construction project teams: The case of Kenya and UK. International Journal of Project Management. Vol 28(5), 449-460. Doi: http://dx.doi.org/10.1016/j.jpproman.2009.08.001

Esa and Nurudin (1998). Policy on Industrilised Building System. Report on Qollocium on Industrilised Construction System, Kuala Lumpur.

Esther Cheung, Albert P.C. Chan, Stephen Kajewski, (2012). Factors contributing to successful public private partnership projects: Comparing Hong Kong with Australia and the United Kingdom. Journal of Facilities Management, Vol. 10 Iss: 1, pp.45-58.

Grossman, G. and E. Helpman (2005). Outsourcing in a global economy. Review of Economic Studies 72: 135-159.

Gunasekaran, A., and Ngai, E.W.T., (2012). Decision Support Systems for logistic and supply chain management. Decision Support System. Volume 52 (4). 777-778. doi:10.1016/j.dss.2011.11.012

Harjeev K. Khanna, D.D. Sharma, S.C. Laroiya, (2011). Identifying and ranking critical success factors for implementation of total quality management in the Indian manufacturing industry using TOPSIS. Asian Journal on Quality, Vol. 12 Iss: 1, pp.124 - 138.

Hassim Mohd. Suffian (2009). The Industrialised Construction System - Pengalaman (The Experience of) PKNS Engineering \& Construction Berhad (PECB) in Colloquium on Industrialised Construction System, CIDB.

Hubbard Douglas (2009). The Failure of Risk Management: Why It's Broken and How to Fix It. John Wiley \& Sons. p. 46.

Ismail, Faridah, Yusuwan, Norazian Mohamad, \& Baharuddin, Har Einur Azrin. (2012). The Management Factors For Successful IBS Projects Implementation. Paper presented at the AicE-Bs 2012 Cairo-ASIA Pacific International Conference on Environment-Behaviour Studies, Egypt.

Kamar, K. A. M., Alshawi, M. \& Hamid, Z. A. (2009) Barriers to Industrialised Building System (IBS): The Case of Malaysia. BuHu 9th International Postgraduate Research Conference (IPGRC) (Eds., Alshawi, M., Ahmed, V., Egbu, C. and Sutrisna, M.), Salford, UK.

Kamar, K.A.M., Alshawi, M., and Abd Hamid, Z., (2010), The Critical Success Factors (CSFs) to Industrialised 
Ismail, F., et.al. / Asian Journal of Environment-Behaviour Studies (ajE-Bs), 3(9) Jul / Aug 2018 (p.169-181)

Building Construction in Malaysia, Paper Proceedings in CIB World Congress 2010, Salford, 10-13 1 May, 2010.

Kwai-Sang Chin, Boris L. Chan, Ping-Kit Lam (2008). Identifying and prioritizing critical success factors for coopetition strategy. Industrial Management \& Data Systems, Vol. 108 Iss: 4,

pp.437 - 454 .

Jeffrey K. Pinto and John E. Prescott (1988). Variations in Critical Success Factors over the Stages in the Project Life Cycle. Journal of Management, 14: 5-18

Jiju Antony, Kevin Leung, Graeme Knowles and Sid Gosh (2002). Critical success factors of TQM implementation in Hong Kong industries. International Journal of Quality and Reliability Management, 19: 551-566, ISSN 0265$671 X$.

Lessing et al. (2005), as stated in Kazi, S., (2007). Open Building Manufacturing-Core Concept and Industrial Requirement. Manubuild Consortium.

Lim P. C. \& Kadir A. M. (2006). Implementation Strategy for Industrialised Building Systems. Master Theses. Universiti Teknologi Malaysia (UTM), Skudai.

Lu, N., (2009). The current use of offsite construction techniques in the United States construction industry. Conference Proceeding Paper Part of: Construction Research Congress 2009: Building a Sustainable Future pp. 946-955. Retrieve from: http://dx.doi.org/10.1061/41020(339)96) on 27 August 2012

L.Jaillon, C.S. Poon, Y.H. Chiang (2009). Quantifying the waste reduction potential of using prefabrication in building construction in Hong Kong. Waste Management. 29(2009). 309-320

Marinez-Moyano, I. J. (2006). Exploring the Dynamics of Collaboration in Interorganizational Settings, Ch. 4, p. 83, in Schuman (Editor). Creating a Culture of Collaboration. Jossey-Bass, ISBN 0-7879-8116-8.

Ma Yi-zhong, Yue Gang, Wang Li-lin and Sangbok Ree (2008). The Critical Success Factors of Six Sigma in China Manufacturing Industry. Asian Journal on Quality, 9(2), 39-56.

Nasrun Nawi (2012). A Preliminary Survey of the Application of Industrialised Building System (IBS) in Kedah and Perlis Malaysian Construction Industry. University Malaya.

Na, L. and Liska, R., W. (2008) Designers and General Contractors Perceptions of Offsite Construction Techniques in the United State Construction Industry, International Journal of Construction Education and Research, 4 (3), 177 $-188$.

Onyeizu, E.N., Abu Bakar, A.H. (2011). Assessing key factors in design in the Industrialised Building System (IBS) approach- Stakeholders' opinion. International Journal of Academic Research. Vol 3(4). 168-175

Pan, W., Gibb, A. G. F. and Dainty, A. R. J. (2007) Perspectives of UK housebuilders on the use of offsite modern methods of construction, Construction Management and Economics, 25 (2), 183-194.

Phil Nixon, Megan Harrington, David Parker, (2012). Leadership performance is significant to project success or failure: a critical analysis. International Journal of Productivity and Performance Management, Vol. 61 Iss: 2, pp.204 $-216$.

Phatsaphan Charnwasununth, Nobuyoshi Yabuki, Tanit Tongthong (2009). A Proposed Collaborative Framework for Prefabricated Housing Construction Using RFID Technology. In Y.Luo (Ed.) LNCS 5738, pp. 372-375.

Rahman, A. B. A, Omar, W. (2006). Issues and Challenge in the Implementation of IBS in Malaysia. Proceeding of the 6th Asia Pacific Structural Engineering and Construction Conference (ASPEC 2006), 5-6 September 2006. Kuala 
Lumpur, Malaysia.

Rashid.A.K (2009) "Industrialised Building Systems: The JKR Perspectives", Malaysian Construction Research Journal (MCRJ); Vol4, No.1, 2009.CREAM. Retrieved from http://malaya.academia.edu/AzlanShahAli/Papers/704599/A_case_studies_of_intelligent_buildings_in_Malaysia on 27 August 2012

Robert Newton, Michael Wilkinson (1995). Critical success in management development. Management Development Review, Vol. 8 Iss: 1, pp.16 - 24.

Saurabh Kumar Saxena (2010). A Review of Marketing Strategies Work by Different Pharmaceutical Companies. Departmant of Management, Rakshpal Bahadur Management Institute.

Shaari, Shahrul Nizar and Ismail, Elias (2003). Promoting the Usage of Industrialised Building Systems (IBS) and Modular Coordination (MC) in Malaysian Construction Industry. Buletin Ingeniur, Board Engineers of Malaysia (BEM), Kuala Lumpur.

Shukor, A.S., Mohammad, M.F., Mahbub, R., Ismail, F. (2011). Supply chain Integration in Industrialised Building System in the Malaysian Construction Industry. The Built \& Human Environment Review, 4 (1). Retrieved from http://www.ikb.poznan.pl/fcee/2005.06/full/fcee_200506_203216_logistics_of_construction.pdf

Sumadi, Salihuddin Radin, et al (2001). Promotion Strategies and Future Research \& Development. National Seminar on Industrialised Building System, CIDB, Kuala Lumpur.

Trikha (1999). Industrialised Building System: Prospect in Malaysia. Proceeding of World Engineering Congress, Kuala Lumpur.

Warszawski, (1999). Industrilised and Automated Building System. Technion-Israel Institute of Technology, E \& FN Spon.

York P. Freund, (1988). Critical success factors: Strategy \& Leadership. Vol. 16 Iss: 4, pp.20 - 23. 